\title{
Population density, habitat dynamic and aerial survival of relict cave bivalves from genus Congeria in the Dinaric karst
}

\author{
Olga Jovanović Glavaš ${ }^{1}$, Branko Jalžić ${ }^{2}$, and Helena Bilandžija ${ }^{3^{*}}$ \\ ${ }^{1}$ Department of Biology, University Josip Juraj Strossmayer, Cara Hadrijana 8/A, 31000 Osijek, Croatia \\ ${ }^{2}$ Croatian Biospeleological Society, Demetrova 1, 10000 Zagreb, Croatia \\ ${ }^{3}$ Department of Molecular Biology, Ruđer Bošković Institute, Bijenička 54, 10000 Zagreb, Croatia; Croatian Biospeleological \\ Society, Demetrova 1, 10000 Zagreb, Croatia
}

\begin{abstract}
Caves are some of the least-known ecosystems on Earth and long-term ecological studies and population size estimates are very rare. Genus Congeria is a Tertiary relict that comprises three species from Dinaric karst area; $C$. kusceri, $C$. jalzici and $C$. mulaomerovici, each with very limited distribution. They are the only known cave bivalves and in contrast to many other cave species, they form populations with high densities. We estimated that the population of C. kusceri in Jama u Predolcu is between 72,454 and 72,906 individuals. The highest density occurred between one and three meters depth, and reached maximum of 1,625 individuals per square meter. Here we also present the results of a two-year water temperature and water level survey in several $C$. kusceri and $C$. jalzici localities. Data loggers showed that $C$. jalzici occurs in colder caves and higher water level oscillations then C. kusceri. From our data, it is obvious that the natural hydrological conditions in Congeria habitats were seriously altered. This and a series of other threats led to Congeria species being highly endangered. During low water levels, a part of the bivalve population becomes exposed to air in most localities. Uniquely, they are active during that period and are able to survive those conditions for more than 2 months.
\end{abstract}

Keywords: $\quad$ cave animals, Dreissenidae, Bivalvia, temperature, water level, aerial survival, population size Received 7 July 2016; Revised 9 December 2016; Accepted 16 December 2016

Citation: Jovanović Glavaš O., Jalžić B. and Bilandžija H., 2017. Population density, habitat dynamic and aerial survival of relict cave bivalves from genus Congeria in the Dinaric karst. International Journal of Speleology, 46 (1), 13-22. Tampa, FL (USA) ISSN 0392-6672 https://doi.org/10.5038/1827-806X.46.1.2020

\section{INTRODUCTION}

Biodiversity in subterranean realm is generally low compared to surface habitats of the same region. This is presumably due to the very specific and often harsh environmental conditions such as the lack of light and low nutrient availability (Gibert \& Deharveng, 2002). In that context, some of the functional species groups are mostly absent in the subterranean ecosystems, i.e., primary producers and primary consumers (herbivores; Mohr \& Poulson, 1966).

Unlike surface habitats where low biodiversity is often coupled to high population densities, in caves population sizes do not seem to be large, at least judging from the time and effort researchers require to collect cave fauna (Trajano, 2001). There are exceptions, and certain species can form large aggregations in some caves (e.g., Fenolio \& Graening, 2009). One of those exceptions are cave bivalves of the genus Congeria which can cover most or all of available surfaces in some localities (H.B., B.J. pers. observ.). However, the total number of individual bivalves in any of the sites has never been assessed and is not known.

Within the last decade and with the application of molecular phylogenetic methods it became apparent that subterranean diversity is often underestimated, and the existence of cryptic species is a very common phenomenon in the subterranean habitats. As a result, the majority of groundwater species and/or lineages have very narrow distributions, regularly not exceeding $200 \mathrm{~km}$ (Trontelj et al., 2009). One of these species is Congeria kusceri, Bole, 1962, which was considered to be the only known troglobiotic bivalve species until recently. Today we know that different populations of previously described $C$. kusceri represent three distinct species (Bilandžija et al., 2013), including Congeria jalzici, Morton \& Bilandžija, 2013 and Congeria mulaomerovici, Morton \& Bilandžija, 2013.

All three species are found in only 15 cave localities in the Dinaric Karst region; 1 in Slovenia, 6 in Croatia, and 8 in Bosnia and Herzegovina (Jalžić, 1998; Jalžić, 
2001; Bilandžija et al., 2013). Their distributions do not overlap and the range of each individual species is actually very small. The most widespread is $C$. kusceri found in 8 localities within the Neretva River basin, in Croatia and Bosnia and Herzegovina. The second widespread is C. jalzici, known from 4 localities; 1 isolated site in Slovenia and 3 in Croatia, within Lika River basin. Congeria mulaomerovici is known from only 3 localities in the Sana River basin in Bosnia and Herzegovina. The most research has been done on $C$. kusceri (e.g., biology and anatomy, Morton et al., 1998; phylogeny, Stepien et al., 2001; life history, Morton \& Puljas, 2013; growth and longevity, Puljas et al., 2014), as some of the caves it inhabits are easily accessible and available for research throughout the year.

Congeria is one of the three extant genera in the family Dreissenidae. Phylogenetic analyses place Congeria in close relationship with Mytilopsis, while nominal genus Dreissena is positioned in a separate clade (Stepien et al., 2001; Bilandžija et al., 2013). All three species of Congeria are considered Tertiary relicts that begun to diverge at the end of Miocene. The related genera Mytilopsis and Dreissena share similarities in their life history traits such as a life span of two years, a high reproductive rate and rapid growth (Morton, 1969; Morton, 1989; Pathy \& Mackie, 1992). In addition, both genera contain highly invasive species on a global scale (i.e., Dreissena polymorpha, (Pallas, 1771), Dreissena bugensis, Andrusov, 1897, Mytilopsis leucophaeata, (Conrad, 1831)). Their reproductive strategy has an advantage for invading new territories and probably explains their success in introduced areas (Borcherding, 1991; Ram et al., 2011). Further, they are most commonly found between 2 and $12 \mathrm{~m}$ of depth and can tolerate a wide range of water salinities and temperatures (Erben et al., 1995; Stanczykowska, 1977).

On the contrary, representatives of genus Congeria have developed some specific and unique features presumably due to their adaptation to subterranean environment. Similarly to other stygobiont species, Congeria kusceri has a long life span of more than 50 years (Puljas et al., 2014) and reaches sexual maturity at the age of 10 years. It has an annual reproductive cycle, produces just a few offspring, and broods early larvae in ctenidia and juveniles in mantle pouches (Morton \& Puljas, 2013). These features contribute to the low recovery potential of these species, making cave bivalves very susceptible to environmental changes.

Congeria kusceri is listed as Vulnerable (VU) in the European Red List of Non-marine Mollusks based on IUCN criteria (Cuttelod et al., 2011). Since C. jalzici and C. mulaomerovici have been described only recently (Morton \& Bilandžija, 2013), their IUCN status has not yet been evaluated on the international level. However, both C. jalzici and C. kusceri in Croatia are listed as Critically Endangered (CR) (Bilandžija \& Jalžić, 2009). They are distributed in areas heavily affected by man-made changes: building of hydroelectric power plants and redirection of water courses left many sinkholes (including Congeria sites) without any influx of water. Unfortunately, human interventions are still ongoing and future plans include another dam in the Lika River basin that will affect at least two but more likely all three C. jalzici localities in Croatia and a series of dams in the upper Neretva River basin in Bosnia and Herzegovina that may have an effect on most or all of the C. kusceri sites.

Congeria species are also included in Annexes II and IV of the Habitat Directive (94/93/ECC). As a part of preparation for admittance of Croatia to the European Union (EU) and the obligations to comply with EU's nature conservation legislation, especially related to implementation of Habitats Directive, we conducted research on Congeria including searches for new localities, visits to all known sites, studies of population ecology and assessments of threats. Here we report some of the results of those multiannual studies.

In the first part we focus on the C. kusceri population from Jama u Predolcu cave, located in the town of Metković, Croatia with the goal to determine the population size. In the second part we describe the results of a two-year water temperature and levels surveys in 3 caves inhabited by C. kusceri: Jama u Predolcu, Pukotina u tunelu Polje Jezero-Peračko Blato, and Žira, as well as in a single C. jalzici locality: Markov Ponor (Fig. 1). We also report on the ability of these species to survive long periods living outside of the water. Our research gives us insights into the basic habitat characteristics of these unique species and is valuable from the species conservation perspective. Since C. jalzici and C. kusceri are under a great threat from both past and future pressures it is important to establish reference points for environmental parameters that can serve for planning future interventions as well as subsequent monitoring of Congeria populations.

\section{MATERIALS AND METHODS}

\section{Density survey}

We estimated the density of the Congeria kusceri population in Jama $u$ Predolcu cave, in the town of Metković, Croatia. This $71 \mathrm{~m}$ long and $20 \mathrm{~m}$ deep cave (Fig. 2) is composed of three chambers: the Entrance Hall, the Speleothem Passage and the Water Passage. A lake at the bottom of the Entrance Hall is divided into the Shallow and Deep Lake by a ridge. The Entrance Hall is illuminated but not much sunlight reaches the level of the lakes which are $10 \mathrm{~m}$ below the entrance. The Speleothem Passage leads to the Water Passage which ends in a Third Lake. This site was chosen because the cave and subterranean lakes are easily accessible throughout the year.

The population size was estimated based on the census of $10 \%$ of the surface in the Shallow and Deep Lake, and $20 \%$ of the surface in the Third Lake. Since the bottom of all three lakes is covered in mud and sediment and does not provide suitable habitat for C. kusceri, counting was performed only on lake walls. Counting lasted over two weeks (in June and September 2012) and was performed by four or five divers. Counting was carried out in squares of 


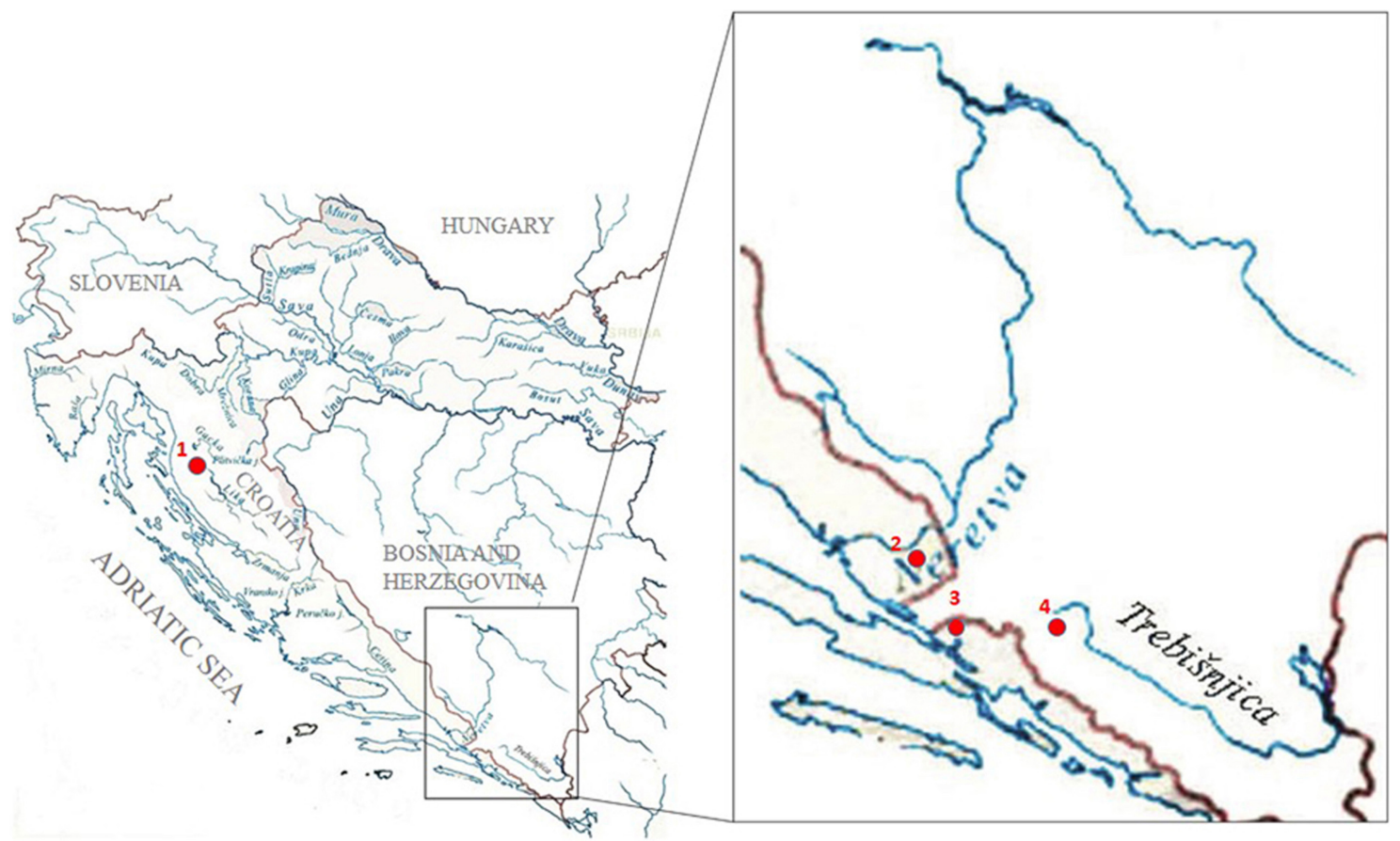

Fig. 1. Congeria kusceri and C. jalzici localities were included in our study. Lika river basin: 1) Markov Ponor; Neretva river basin: 2) Pukotina u tunelu polje Jezero - Peračko Blato, 3) Jama u Predolcu, and 4) Žira.

$40 \times 40 \mathrm{~cm}$, which were divided in four $20 \times 20 \mathrm{~cm}$. The squares were placed diagonally to the next square from the surface to the bottom, i.e., upper left corner of the new counting square would be positioned according to placement of the lower right corner of the preceding square. The starting points for each of the diagonal were $4 \mathrm{~m}$ apart in the Shallow and Deep Lake, and $2 \mathrm{~m}$ apart in the Third Lake.

Data obtained by census of sample plots were used as a basis for population size estimation. The

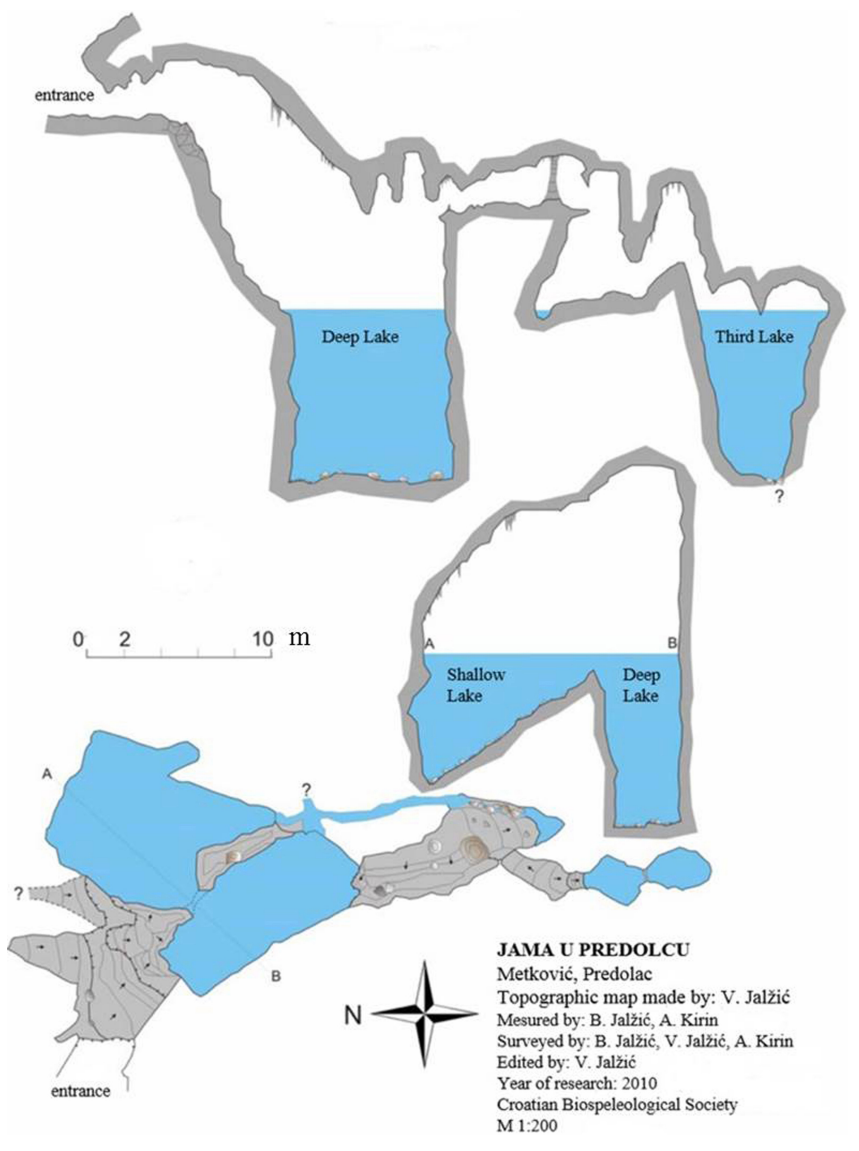

Fig. 2. Map of Jama u Predolcu Cave. estimation was calculated following Hanson (1967) since both of the presumptions for this method were met; i.e., the animals were sampled at random, and all the animals existing on each plot were counted only once. The method is based on the mean number of animals recorded per each plot, and the variance of the mean, which is used to calculate the 95\% confidence limit. The results are then extrapolated to the whole surface of lake walls.

In order to examine a possible correlation between the number of bivalves and depth, correlation coefficient was calculated for each lake separately. Data were grouped by meters of depth for each of the lakes ( $0 \mathrm{~m}$ to maximum $9 \mathrm{~m}$ in the Deep Lake) and examined with nonparametric Spearman's rank order correlation test, with significance level of $\mathrm{P}<0.05$. Analyses were performed using STATISTICA software (StatSoft Inc., 2014).

\section{Water level and temperature data}

We placed data loggers (HOBO 250-Foot Depth Water Level Data Logger, Onset, USA) in three $C$. kusceri and one C. jalzici cave. All three C. kusceri caves are in the Neretva River catchment. The Žira and Jama u Predolcu caves are part of the Trebišnjica river basin, a left tributary of the Neretva River, whereas the Pukotina $u$ tunelu Polje Jezero-Peračko Blato Cave is located on the right bank of the Neretva River. The Žira Cave is a sinkhole of the Trebišnjica River and is located upstream of the Jama u Predolcu Cave. The Jama $u$ Predolcu receives water mostly from the Trebišnjica River but its water level is also influenced by the Neretva River since it is situated directly in the Neretva river valley.

Data loggers recorded water level and temperature every 45 minutes. Data logger was placed in the Shallow Lake of Jama u Predolcu Cave, and recorded data from 23 June 2010 until 19 September 2012, in total for the period of 816 days. In the 
Pukotina u tunelu Polje Jezero-Peračko Blato data was collected between 18 September 2010 and 14 September 2012, for a total of 726 days. A third data logger was placed in Žira Cave in the period from 3 September 2011 until 8 September 2012 (370 days).

Water level and temperature data for $C$. jalzici was monitored in Markov Ponor, a sinkhole in Lika River Basin, located over $250 \mathrm{~km}$ northwest from the Neretva River and C. Kusceri sites. Data was recorder from 8 September 2010 until 21 September 2012, for a period of 744 days. On 18 October 2011 the data logger was moved to another more secluded place, since it was detached from the original spot and was found lying in the rocks $2 \mathrm{~m}$ away.

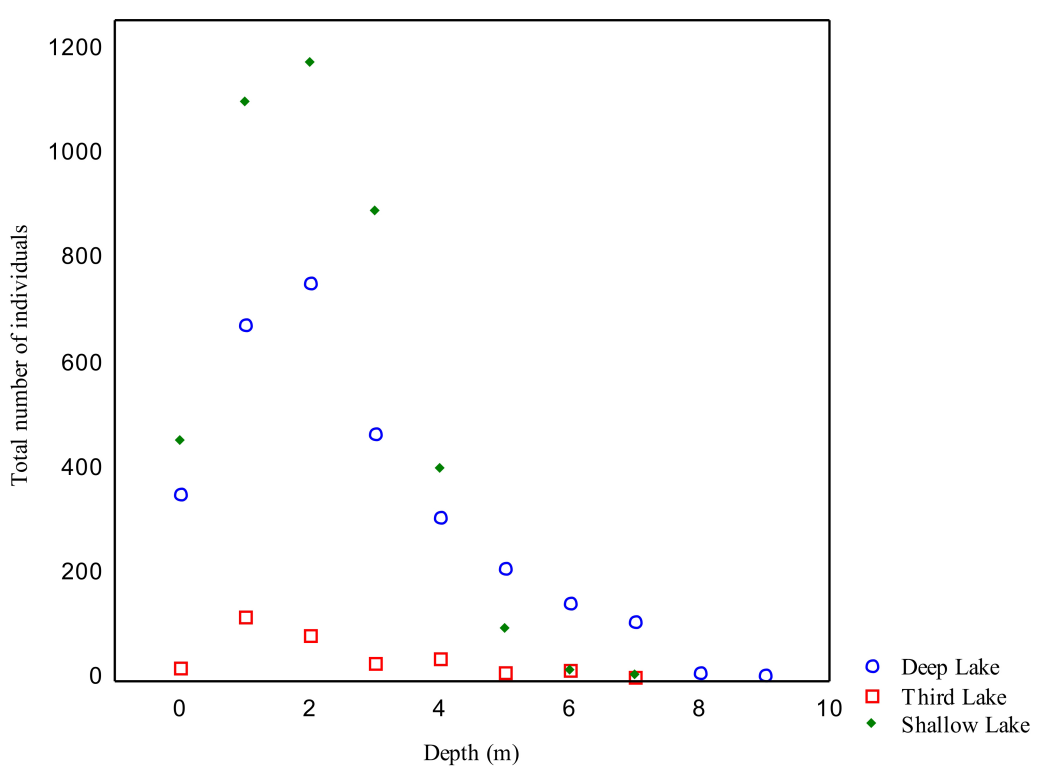

\section{RESULTS}

Fig. 3. Density of individuals recorded on different depths in Jama u Predolcu Cave.

\section{Density survey}

We counted a total of 7,412 individuals in all three lakes of Jama $u$ Predolcu cave. The highest number was registered in the Shallow Lake, 4,111 individuals, 3,010 individuals in the Deep Lake, and 291 individuals in the Third Lake. Based on these results, we estimated the number of individuals for all tree lakes; the population ranges between 40,995 and 41,240 individuals in the Shallow Lake, between 30,024 and 30,185 individuals in the Deep Lake, and from 1,435 to 1,481 individuals in the Third Lake. Altogether, the population size for the Jama u Predolcu Cave ranges between 72,454 and 72,906 individuals.

The density of individuals varied considerably, both among and within lakes, and depended on the microhabitat conditions and depth in each of the lakes. The highest total density was recorded in the Shallow Lake, where mean density was $211 \pm 305$ individuals per square meter (ind $/ \mathrm{m}^{2}$ ). The recorded mean density was $103 \pm 201 \mathrm{ind} / \mathrm{m}^{2}$ in the Deep Lake, and $59 \pm 111 \mathrm{ind} / \mathrm{m}^{2}$ in the Third Lake.

Our analyses showed that there is a correlation between the depth and the number of individuals, in all three lakes, although it was not significant in the Third Lake (Third Lake P > 0.05, $\mathrm{r}=-0.62$; Shallow Lake $\mathrm{P}<0.05, \mathrm{r}=-0.75$; Deep Lake $\mathrm{P}<0.01, \mathrm{r}=-0.84)$. The highest density of individuals was observed between 1 and $3 \mathrm{~m}$ of depth (Fig. 3); in the Shallow Lake the average density between 1 and $3 \mathrm{~m}$ was $267 \pm 333$ ind $/ \mathrm{m}^{2}$ with maximal value of $1625 \mathrm{ind} / \mathrm{m}^{2}$, in the Deep Lake the average was $192 \pm 286 \mathrm{ind} / \mathrm{m}^{2}$ and in the Third Lake $107 \pm 153$ ind $/ \mathrm{m}^{2}$. Such high standard deviations are a result of the fact that bivalves are very patchily distributed on cave walls; in certain areas they form large congregations whereas in other, such as smooth surfaces, they are not present at all.

\section{Water level and temperature data}

In Jama u Predolcu Cave, the data logger collected 25,975 records of temperature and water level in the period of 816 days. The data are shown in Table 1 and Fig. 4. There are several abrupt peaks in water level, short in both the size ( $\max 2 \mathrm{~m})$ and duration. The fact that natural hydrological conditions are interrupted is obvious from the irregular pattern of peak occurrence (October and November 2010, and February and April 2012) including no high peaks in 2011. The temperature data is more in accordance with expected values; peak temperatures of above $18^{\circ} \mathrm{C}$ were recorded in summer months each year and lower values (around $13^{\circ} \mathrm{C}$ ) in winter months.

In the Pukotina u tunelu Polje Jezero-Peračko Blato Cave the data logger recorded 23,253 measurements in the period of 726 days. The data are shown in Table 1 and Fig. 5. A period of low water levels started in June of both 2011 and 2012. Water levels began rising in late autumn, followed by oscillations during the whole winter and spring with several high peaks throughout that period. Temperature data shows that the lowest temperatures coincide with highest water levels and vice versa. For example, the highest water level peak recorded in November/ December 2010 coincided with the lowest recorded temperature $\left(7.18^{\circ} \mathrm{C}\right)$.

In Žira Cave the data logger recorded 11,879 measurements in a period of 370 days (Table 1 and Fig. 6). A flat line in the water level data is present because the data logger was above the water for most of the time. Consequently, the details for water level changes during the low water levels are missing. High peaks (> $0.5 \mathrm{~m}$ change) occurred in December 2011, and February and April 2012. The temperature in the cave was very stable throughout the recording period, with a total variation of only $1.08^{\circ} \mathrm{C}$.

In Markov Ponor sinkhole the data logger recorded a total of 23,695 measurements during 744 days (Table 1 and Fig. 7). However, due to the detachment of the data logger, on 18 October 2011 it had to be moved to a more protected spot where the chances that water current would detach it again were minimized. Therefore, during first period from 08 September 2010 until 17 October 2011, 12,910 measurements were recorded, and from 18 October 2011 until 21 September 2012, 10,761 measurements. Other than just a few peaks, the water level was about the same 
Table 1. Data logger measurements on three sites, Jama u Predolcu, tunnel between Polje Jezero-Peračko Blato, and Žira. N: number of measurements, T max: highest recorded temperature, $\mathrm{T}$ min: lowest recorded temperature, $\mathrm{T}$ mean $\pm \mathrm{SD}$ : average temperature at the site in the measured period \pm standard deviation, $\mathrm{H}_{2} \mathrm{O}$ max: highest water level recorded at the site, $\mathrm{H}_{2} \mathrm{O}$ min: lowest water level recorded at the site, $\Delta$ depth: difference between the highest and lowest water level, $\mathrm{H}_{2} \mathrm{O}$ mean $\pm \mathrm{SD}$ : mean water level \pm standard deviation.

\begin{tabular}{|c|c|c|c|c|c|c|c|c|c|c|c|c|}
\hline Site & $\mathbf{N}$ & $\begin{array}{l}T \text { max } \\
{ }^{\circ} \mathbf{C}\end{array}$ & Date $\max$ & $\underset{T}{\mathbf{T}} \min$ & Date min & $\begin{array}{l}T \text { mean } \\
\pm \mathrm{SD}^{\circ} \mathrm{C}\end{array}$ & $\begin{array}{c}\mathrm{H}_{2} \mathrm{O} \text { max } \\
\text { (m) }\end{array}$ & Date $\max$ & $\begin{array}{l}\mathrm{H}_{2} \mathrm{O} \\
\mathrm{min} \\
(\mathrm{m})\end{array}$ & Date min & $\begin{array}{c}\Delta \text { depth } \\
\text { (m) }\end{array}$ & $\begin{array}{c}\mathrm{H}_{2} \mathrm{O} \\
\text { mean } \\
\pm \mathrm{SD}(\mathrm{m})\end{array}$ \\
\hline $\begin{array}{l}\text { Jama u } \\
\text { Predolcu }\end{array}$ & 25975 & 19.38 & 9.8 .2012 & 11.63 & 6.2 .2012 & $\begin{array}{r}15.38 \\
\pm 2.00 \\
\end{array}$ & 3.01 & 23.11 .2010 & 0.97 & 1.12 .2011 & 2.04 & $\begin{array}{c}1.51 \\
\pm 0.26 \\
\end{array}$ \\
\hline $\begin{array}{l}\text { Polje Jezero } \\
\text {-Peračko } \\
\text { Blato }\end{array}$ & 23253 & 17.48 & 3.5 .2012 & 7.18 & 18.12 .2010 & $\begin{array}{r}13.47 \\
\pm 1.84\end{array}$ & 11.97 & 28.11 .2010 & 0.59 & 21.10 .2011 & 10.38 & $\begin{array}{c}4.06 \\
\pm 2.94\end{array}$ \\
\hline Žira Cave & 11879 & 11.14 & 12.5 .2012 & 10.06 & 4.2 .2012 & $\begin{array}{r}10.95 \\
\pm 0.18\end{array}$ & 2.35 & 17.4 .2012 & -0.26 & 3.2 .2012 & 2.61 & $\begin{array}{l}-0.07 \\
\pm 0.34\end{array}$ \\
\hline $\begin{array}{l}\text { Markov } \\
\text { Ponor }\end{array}$ & 23695 & 10.46 & 28.10 .2010 & 2.09 & 19.12 .2010 & $\begin{array}{c}5.46 \\
\pm 0.77\end{array}$ & 59.53 & 8.12 .2010 & -0.48 & 19.9 .2011 & 60.01 & $\begin{array}{c}5.14 \\
\pm 9.97\end{array}$ \\
\hline
\end{tabular}

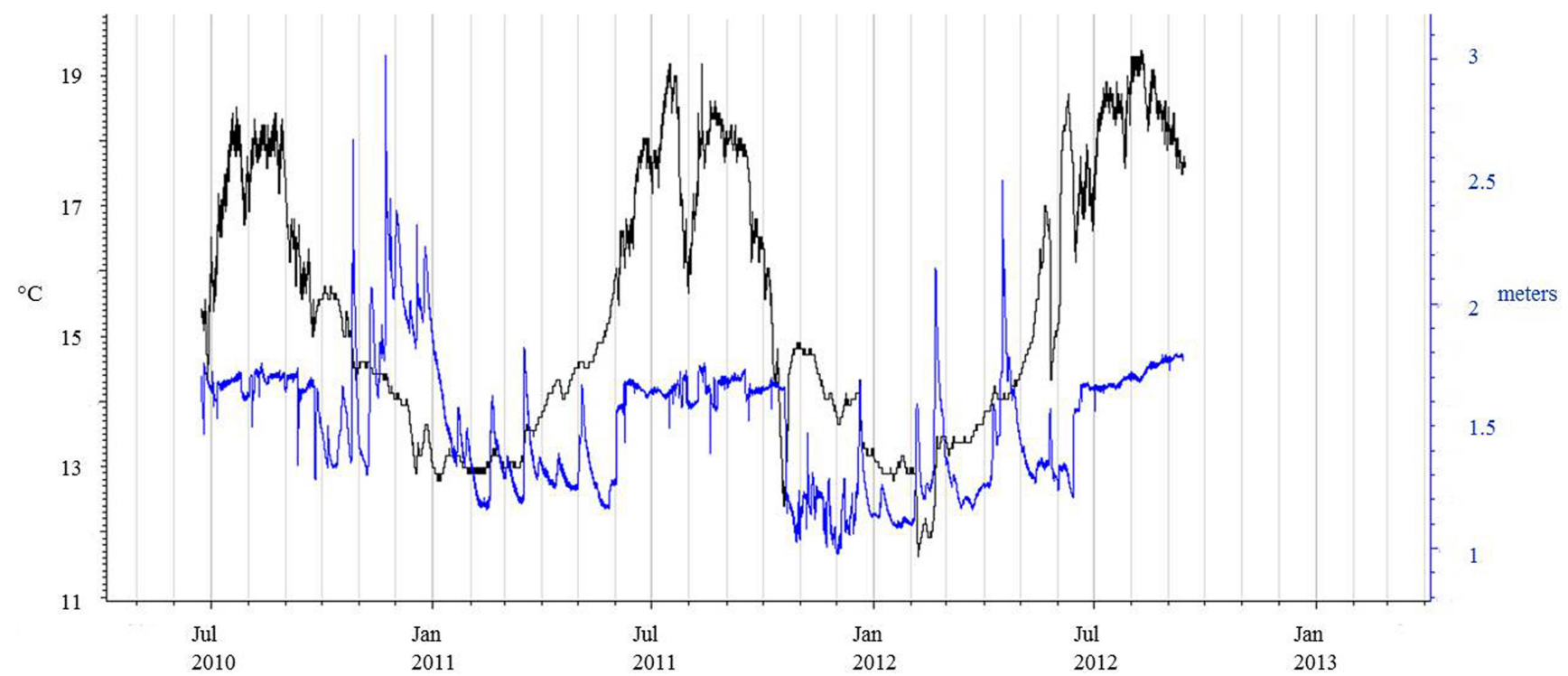

Fig. 4. Water level (blue) and temperature (black) in Jama u Predolcu from 23 June 2010 untill 19 September 2012.

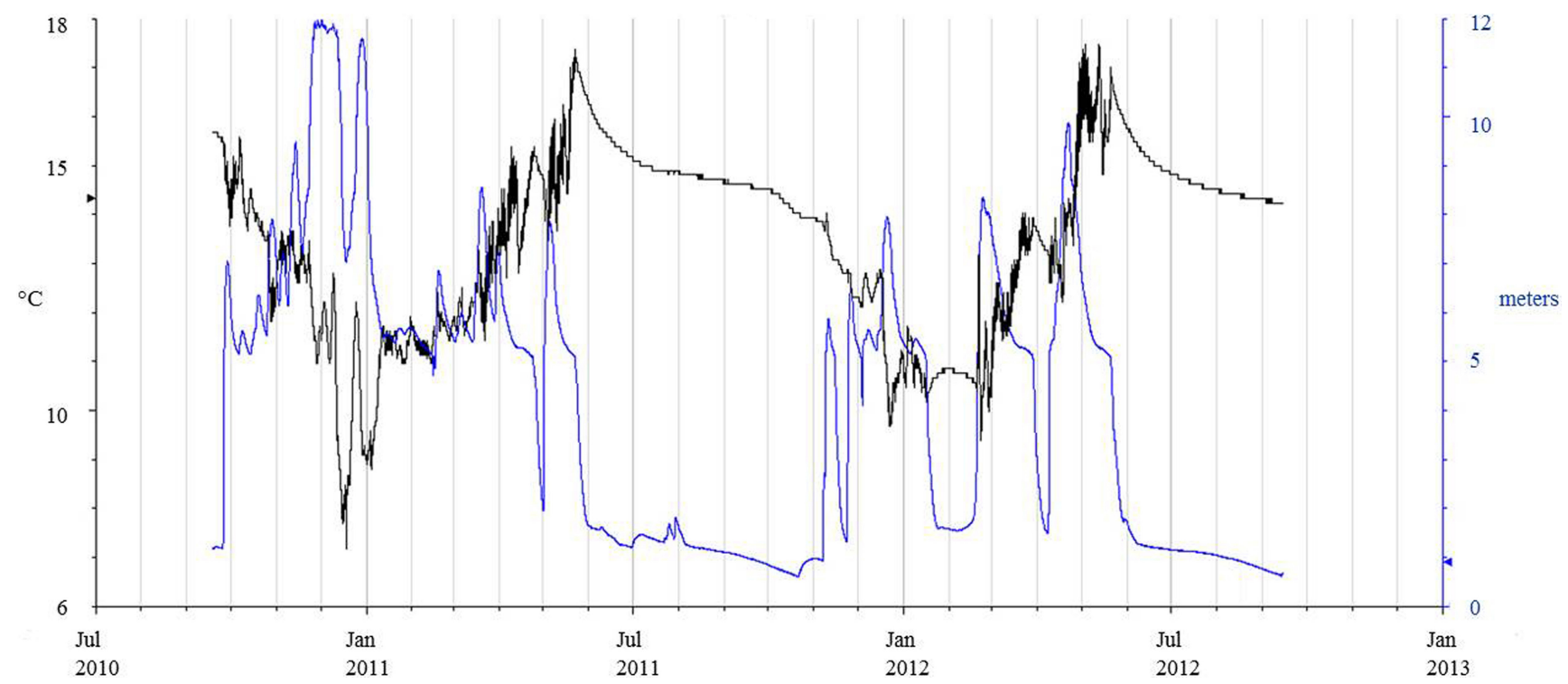

Fig. 5. Water level (blue) and temperature (black) in Pukotina u tunelu Polje Jezero- Peračko Blato from 18 September 2010 untill 14 September 2012.

and followed a predictive pattern. Starting in June 2011, the water level dropped, reaching the lowest point in early to mid-August; in late autumn it increased several meters and then showed only slight oscillations from December to June. The highest change in water level was recorded on 31 November 2010 when water level had risen for $40 \mathrm{~m}$ in 90 minutes, and in the next four hours it reached $50.63 \mathrm{~m}$ (Fig. 7). The total difference of water level in Markov Ponor was slightly above $60 \mathrm{~m}$. The data logger was outside of the water two times, from mid October to mid December 2011 and beginning of August to the end of September 2012. Both periods are characterized by more substantial 


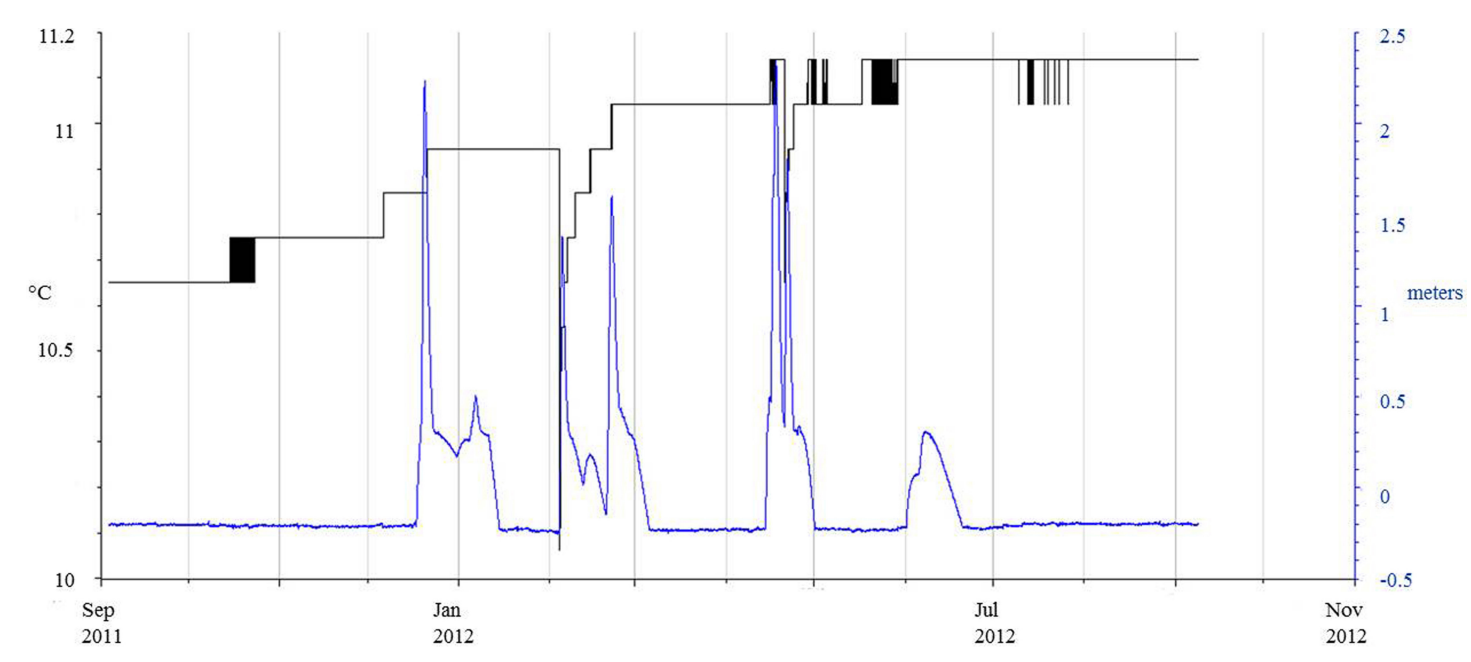

Fig. 6. Water level (blue) and temperature (black) in Žira Cave between 3 September 2011 to 8 September 2012.

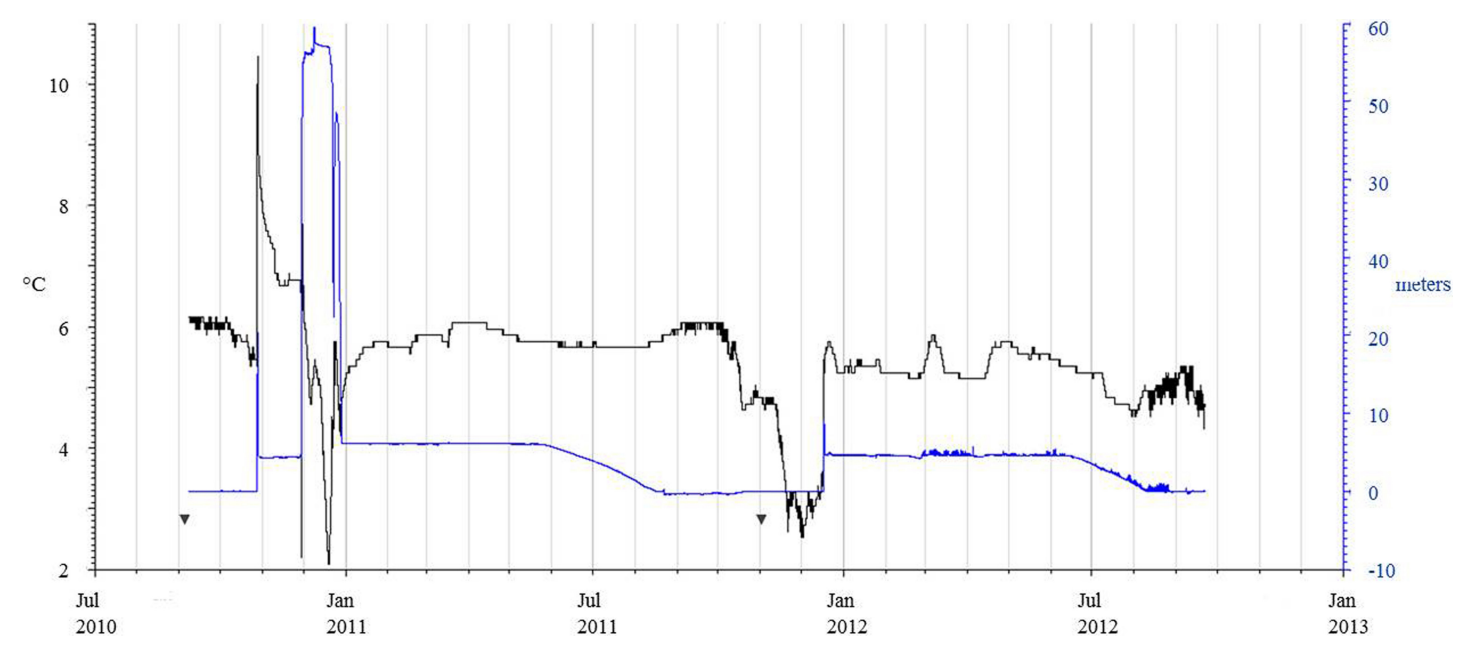

Fig. 7. Water level (blue) and temperature (black) in Markov Ponor from 8 September 2010 till 21 September 2012.

temperature variations as it would be expected from the air compared to water temperature patterns. The temperatures in Markov Ponor varied between $5^{\circ} \mathrm{C}$ and $6^{\circ} \mathrm{C}$ throughout most of the research period. Both the maximum and minimum recorded temperatures occurred within just two months (October to December 2010) and coincided with high peaks in the water level data. First, at the end of October 2010 a rise of approximately $20 \mathrm{~m}$ in water level caused a steep temperature increase to $10.45^{\circ} \mathrm{C}$, and in the second half of December 2010, the $60 \mathrm{~m}$ water level rise caused a decrease of temperature almost to $2^{\circ} \mathrm{C}$. A second substantial drop in the temperature, to less than $3^{\circ} \mathrm{C}$ occurred in late autumn 2011 and was caused by the water level drop and the data logger not being submersed.

\section{Aerial survival}

We have observed Congeria individuals from all three species living on air-exposed cave walls for a part of the year. The proportion of the population that gets exposed to air is small but it happens in most localities: for C. kusceri it is Žira, Pukotina $u$ tunelu Polje Jezero-Peračko Blato, Jasena, Gradnica, Doljašnica, and Plitica; for C. jalzici it is Markov Ponor and Dankov Ponor; and for C. mulaomerovici Suvaja and Dabarska pećina. Only in five localities bivalves do not get exposed to air and these localities are mostly springs with direct outlet towards the surface where, as far as we know, there is no dry rock surface in the cave itself.

During the period of low water levels in Markov Ponor, the period of air exposure that bivalves were able to survive lasted for more than two months. Often, patches of bivalves living outside of the water were found in passages that were far away (tens of meters) from remaining lakes and ponds which excludes the possibility that they migrate in and out of the water. Interestingly, we would invariably find individuals with their shells open and inhalant and exhalant syphons extruded (Fig. 8).

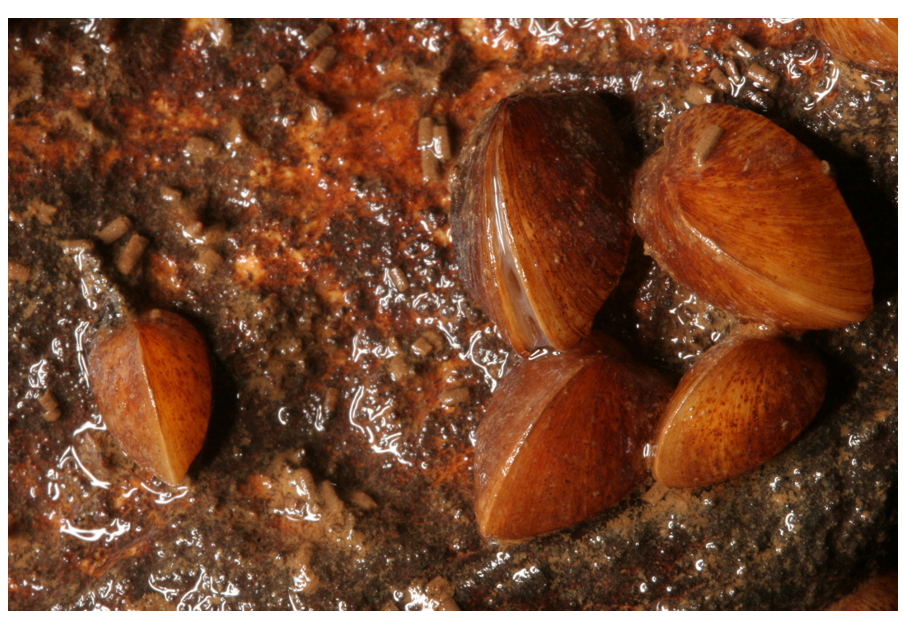

Fig. 8. An individual with open shells found outside of the water in Markov Ponor (photo by H. Bilandžija). 


\section{DISCUSSION}

The densities of individuals in extreme environments, such as caves, are usually limited due to the low food availability. This applies to the majority of stygobiont species; for example, cave populations of fishes are generally smaller than of those living in epigean habitats (Trajano, 1997; Bichuette \& Trajano, 2015). There are exceptions like the sulpidic, nutrient rich caves where the animals live in high density populations (e.g., Jourdan et al., 2014). We have observed Congeria bivalves forming dense populations during our field surveys. Results of the population size study show that $C$. kusceri can live in populations with up to 1625 individuals per square meter. The reason for such high density could be related to a filter feeding life style of this species. There are two more sedentary filter feeders in the Dinaric Karst, the cave sponge Eunapius subterraneus Sket \& Velikonja, 1984 and the cave tube worm Marifugia cavatica, Absolon \& Hrabe, 1930 which co-occurs with Congeria at all sites. Both the sponge and the tube worm can form large colonies and live in dense populations (H.B., B.J. pers. observ.). In addition, Stygobromus emarginatus (Hubricht, 1943), a non-sedentary filter feeding amphipod, also has high population sizes (Knapp \& Fong, 1999). Filter feeding therefore seems to be a good feeding strategy that can sustain large populations of subterranean animals.

High densities of cave bivalves suggest that subterranean waters they inhabit might be rich in organic matter. Changes in water levels, as indicated by our data, are very rapid and presumably can carry a rich supply of organic matter from the surface to the subterranean realm which would be the basis for sustaining large colonies of filter feeders. For example, C. jalzici lives in the sinkholes which are likely more nutrient rich due to the influx of organic matter with the water from the surface. Congeria kusceri lives in caves with various hydrological functions but it has been found only in the most downstream parts of the Neretva River basin. Water sinking and resurfacing in the upper parts of the catchment likely contributes to organic matter enrichment so that there are enough nutrients to sustain large colonies of bivalves (and in some sites cave tube worms too) in the downstream parts of the basin. Measurements of nutrient concentrations along river basins are needed to confirm this hypothesis but was outside the scope of this paper.

Other species in the family Dreissenidae also live in high density populations. Moreover, invasive species of dreissenid mussels are known to overgrow any sort of hard substrate (including other bivalves), and their densities in infested areas are commonly higher than few thousand ind $/ \mathrm{m}^{2}$ (Burlakova et al., 2006; Strayer \& Malcolm, 2006; Nalepa et al., 2010). There are big differences in bivalve densities between different lakes in Jama u Predolcu. The low density in the Third Lake is potentially a consequence of the lower nutrient availability. Namely, sunlight reaches the surface of lakes in the Entrance hall and can potentially enable the growth of some photosynthetic organisms which can in turn form the basis of the food web. Further research is needed to test this hypothesis. The difference between bivalve densities in the Deep and Shallow lakes in the Entrance Hall can be explained by the micro relief. The Deep Lake has mostly simple and smooth cave walls, whereas the Shallow Lake has very rugged cave walls and therefore a greater surface for attachment of the animals.

Depth distribution of individuals shows resemblance in all three lakes. Congeria kusceri prefers depths between 1 and $3 \mathrm{~m}$, with the peak at around $2 \mathrm{~m}$ depth in all three lakes (Fig. 3), which corresponds to some of the dreissenid species which also prefer shallow waters (e.g., D. polymorpha which is commonly found between one and 30 m; Stanczykowska, 1977; Mackle et al., 1989; Snyder et al., 1997).

Interestingly, Congeria bivalves are able to survive extended periods outside of the water, which is not a commonly encountered phenomenon. According to our data from Markov Ponor, these periods can last for more than 2 months. Remarkably, during those times we have observed C. jalzici individuals with their valves slightly open and exhalant and inhalant siphons ejected suggesting they are not dormant (Fig. 8). Some estuarine bivalves can survive outside the water, but for much shorter time periods (hours to several days; e.g., Hiroki, 1977). In addition, several freshwater mussels can survive up to one year buried in mud, but their shells are airtight closed (e.g., Velesunio ambiguous; Jones, 2007), and they lose up to $40 \%$ of their body mass. Further, effects of desiccation depend upon temperature, and a cooler environment (like the one Congeria inhabits) means shorter survival time (Firth et al., 2011; Urian et al., 2011). In the closely related dreissenid species $D$. polymorpha and $D$. bugensis, emersion tolerance is lower than in other freshwater species, and at temperatures below $25^{\circ} \mathrm{C}$ and higher relative humidity, individuals are able to survive slightly more than 10 days (McMahon et al., 1993; Ussery \& McMahon, 1995). So this trait in Congeria maybe evolved as a response to specific karst subterranean conditions where water level changes can be very severe. A big advantage in caves is that the air humidity is very high, often around $100 \%$, so the threat of desiccation is minimized. However, the fact that bivalves have their shells open implies they may be extracting food or oxygen from the thin layer of water or just drops of water dripping over them from the cave ceiling. If so, this would be a unique adaptation in bivalves, and could help them to survive long periods outside of the water.

According to our data C. kusceri lives in a range of temperatures from 7.2 to $19.4^{\circ} \mathrm{C}$. Previously reported temperatures are in the higher range; Morton et al. (1998) and Puljas et al. (2014) reported temperature of $13.5^{\circ} \mathrm{C}$, whereas Jalžić (1998) temperatures between 14.5 and $19^{\circ} \mathrm{C}$, probably because most of stygofauna research is done in the summer when water levels are low. The highest temperatures in C. kusceri localities were recorded in May 2012, except in Jama u Predolcu Cave where the peak was in August 2012. Low temperature extremes are always accompanied 
by a water level rise meaning that an influx of cold water from the surface causes them. For instance, the lowest temperature in Žira and Jama u Predolcu caves was recorded at the same time, in February 2012, and was caused by the water level rise in the whole Trebišnjica river basin. In Pukotina u tunelu Polje Jezero-Peračko Blato and Markov Ponor the lowest temperature was recorded in December 2010 which coincides with the highest water level peak recorded in our study, suggesting that a heavy rainfall or other weather event filled up subterranean aquifers with cold water.

Temperature variations in Žira Cave were minimal $\left(\Delta=1.08^{\circ} \mathrm{C}\right)$ because of hydrotechnical changes in Trebišnjica basin. The river was channeled into a concrete riverbed and the sinkholes were cut off from the water supply (except maybe during very high levels) leaving precipitation as the only source of water in the subterranean portion of the basin. This is also the cause of only $2-2.6 \mathrm{~m}$ water level change in both localities in Trebišnjica basin, Jama u Predolcu and Žira cave. Temperature variations were higher for the other two C. kusceri sites (Jama u Predolcu $\Delta=7.75^{\circ} \mathrm{C}$, Pukotina u tunelu Polje Jezero-Peračko Blato $\Delta=10.27^{\circ} \mathrm{C}$ ) as well as in C. jalzici site (Markov Ponor $\Delta=8.37^{\circ} \mathrm{C}$ ). However, both temperature and water levels can change very rapidly indicating that Congeria species are not highly sensitive to variations in environmental conditions.

The highest water level peaks tended to coincide in all four localities (November/December 2010) and are probably a consequence of the autumn with above average rainfall, especially in south Croatia. Another event in the Neretva river basin that is evident in all three C. kusceri sites happened in February/April 2012. The lowest water levels occurred in autumn 2011 but do not exactly match in different localities and are probably a result of a dry summer/autumn in the whole region. However, it is also obvious from water level data that natural hydrological conditions are very disturbed. In general, one would expect a trend of low water levels and high temperatures during the summer and the opposite during the winter, but there are many exceptions (e.g., high water levels from June to beginning of October 2011 in Jama u Predolcu or occurrence of peak temperatures in Pukotina u tunelu Polje JezeroPeračko Blato in May of both 2011 and 2012). In addition to hydrotechnical changes in Trebišnjica basin (already explained above) another reason for these events could be the use of uncontrolled quantities of water for agricultural purposes, which has been observed in some tributaries of Neretva River (Bonacci et al., 2012). Lika river basin, which is characterized by extreme and very quick changes in its discharge, has been heavily impacted by human activities as well, and for the same purpose: electric energy production (Bonacci \& Andrić, 2008). Markov Ponor has been cut off from the river and no water sinks into the cave, although excess water is released into the sinkhole during high water conditions to prevent flooding of Lipovo Polje, as in the autumn of 2010.
It is unknown exactly how the hydrological modifications described above affected Congeria populations because there was no research on Congeria at the time the changes were made, but we can deduce that they had devastating consequences. For example, Bole (1962) reported that Congeria was growing like clusters of grapes in the last chamber of Žira Cave. Today only individual bivalves can be seen on the walls in the deepest part of the cave. The water level in Jama u Predolcu dropped by 10 $\mathrm{m}$, after Trebišnjica river dam was built. Since today the maximum depth of the lakes in the cave is 10 $\mathrm{m}$, it is possible that more than half of the Congeria population was destroyed at that time. Further, thick layers of dead shells can be found throughout the passages of Markov Ponor, suggesting a catastrophic event, probably not too long ago. The large hydrological changes in the basin when the Lika hydroelectric power plant was built are the likely cause. In addition, bivalves vanished from two previously known localities: Crni Ponor and Izvor kod kapele Sv. Mihovila. In the latter one we found a Congeria population in the mid 1990 but 20 years later there were no bivalves in the spring. The entrance to the spring was widened and today daylight penetrates into the entire cave including the subterranean pool where bivalves used to live, which may have caused their disappearance.

There are a number of other threats to Congeria populations: karst waters are in general very susceptible to contamination from domestic sources and agricultural runoff, and water extraction which can significantly reduce the water levels in the underground water bodies. In addition, tourism development in cave systems can also influence the subterranean habitats and fauna. Unfortunately, in the last few years Jama u Predolcu has also been used as a tourist site, and many changes were made without the proper assessment of the effects on Congeria and other fauna, and without establishing a baseline for subsequent monitoring of the habitat quality and Congeria population health.

Although population from Jama u Predolcu seems to be large and vigorous, it is important to stress that all three species of genus Congeria have been found in only 15 caves. Since Congeria is a long lived and slowly reproducing animal, it is highly sensitive to habitat changes. Data on ecology and population sizes are urgently needed to establish management plan for all three species, and for the whole distribution area, similarly to the plan already developed for Croatia (Bilandžija et al., 2014). Conservation of subterranean fauna and habitats should be of the highest priority since karst system in the Dinaric mountains is considered to be one of the most unique underground systems in the world (Culver \& Sket, 2000; Deharveng et al., 2012).

\section{CONCLUDING REMARKS}

Bivalve species from genus Congeria are sedentary filter feeders. Unlike majority of cave species, they form populations with high densities. We estimated 
the population size of Congeria kusceri in Jama $\mathrm{u}$ Predolcu and it is between 72,454 and 72,906 individuals. The highest density, reaching maximum of 1,625 individuals per square meter, similar to surface species from the family Dreissenidae, was observed between 1 and $3 \mathrm{~m}$ of depth.

Dinaric karst region, as one of the globally important subterranean hotspots, is under strong anthropogenic pressure. Our data show that hydrotechnical interventions have impacted all Congeria sites we monitored and due to the interconnectivity of the whole karst system they have likely influenced all $C$. kusceri and C. jalzici localities. This is clearly visible in the water level data that do not follow the expected natural cycle. Our results show that $C$. jalzici lives in colder caves and is exposed to much higher water level oscillations than C. kusceri. During periods of low water some of the bivalves become exposed to air, a condition that lasts for more than two months. Uniquely among bivalves, we found individuals exposed to the air to be active during that period.

\section{ACKNOWLEDGMENTS}

We are very grateful to cave divers that helped us count the bivalves: Robert Baković, Jana Bedek, Vedran Jalžić and Alen Kirin. In addition, a number of other cave researchers and friends helped during the field work: Ana Komerički, Kazimir Miculinić, Domagoj Tomašković, Tatjana Vujnović, Andrej Turina, and Markica Vujica. The financial support for the research was provided by The State Institute for Nature Protection, Zagreb, Croatia and The Environmental Protection and Energy Efficiency Fund, Zagreb, Croatia. We are grateful to the Ministry of Culture, Directorate for Nature Protection for issuing the research permits. We are also very grateful to prof. W.R. Jeffery for his useful comments on the manuscript.

\section{REFERENCES}

Bichuette M.E. \& Trajano E., 2015 - Population density and habitat of an endangered cave fish Eigenmannia vicentespelaea Triques, $1996 \quad$ (Ostariophysi: Gymnotiformes) from a karst area in central Brazil. Neotropical Ichthyology, 13 (1): 113-122.

http://dx.doi.org/10.1590/1982-0224-20140095

Bilandžija H. \& Jalžić B., 2009 - Dinaric cave clam, Congeria kusceri Bole, 1962. In Ozimec R. (Ed.), Red book of Croatian cave dwelling fauna. Ministry of Culture, State Institute for Nature Protection, Zagreb, Republic of Croatia, p. 67-68.

Bilandžija H., Morton B., Podnar M. \& Ćetković H., 2013 - Evolutionary history of relict Congeria (Bivalvia: Dreissenidae): unearthing the subterranean biodiversity of the Dinaric Karst. Frontiers in Zoology, 10: 5. http://dx.doi.org/10.1186/1742-9994-10-5

Bilandžija H., Puljas S. \& Čuković T., 2014 - Protocol for monitoring of the cave bivalves Congeria kusceri Bole, $1962 i$ Congeria jalzici Morton \& Bilandžija, 2013 in the Republic of Croatia. Croatian Biospeleological Society, Zagreb, 48 p.

Bole J., 1962 - Congeria kusceri sp. n. (Bivalvia, Dreissenidae). Biološki Vestnik 10: 55-61.
Bonacci O. \& Andrić I., 2008 - Sinking karst rivers hydrology: case of the Lika and Gacka (Croatia). Acta Carsologica, 37 (2): 185-196. http://dx.doi.org/10.3986/ac.v37i2.146

Bonacci O., Željković I. \& Galić A., 2013 - Karst rivers' particularity: an example from Dinaric karst (Croatia) Bosnia and Herzegovina). Environmental Earth Sciences, 70 (2): 963-974.

http://dx.doi.org/10.1007/s12665-012-2187-9

Borcherding J., 1991 - The annual reproductive cycle of the freshwater mussel Dreissena polymorpha Pallas in lakes. Oecologia, 87 (2): 208-218. http://dx.doi.org/10.1007/BF00325258

Burlakova Lyubov E., Karatayev A.Y. \& Padilla D.K., 2006 - Changes in the distribution and abundance of Dreissena polymorpha within lakes through time. Hydrobiologia, 571: 133-146.

http://dx.doi.org/10.1007/s10750-006-0234-9

Culver D.C. \& Sket B., 2000 - Hotspots of subterranean biodiversity in caves and wells. Journal of Cave and Karst Studies, 62 (1): 11-17.

Cuttelod A., Seddon M. \& Neubert E., 2011 - European red list of non-marine Molluscs. Luxembourg. Publications Office of the European Union.

http:/ / ec.europa.eu/environment/nature/conservation/ species/redlist/downloads/European_molluscs.pdf

Danielopol D.L., Artheau M. \& Marmonier P., 2009 - Site prioritisation for the protection of rare subterranean species - the cases of two ostracods from south-western France. Freshwater Biology, 54 (4): 877-884.

http://dx.doi.org/10.1111/j.1365-2427.2008.02033.x

Deharveng L., Gibert J. \& Culver D.C., 2012 - Diversity patterns in Europe. In: White W.B. \& Culver D.C. (Eds.), Encyclopedia of caves (2 ${ }^{\text {nd }}$ Ed.). Elsevier: Amsterdam, p. 219-227.

http://dx.doi.org/10.1016/B978-0-12-383832-2.00030-X

Erben R., Lajtner J., Leiner S. \& Bjelić S., 1995 Horizontal and vertical distribution of the zebra mussel (Dreissena polymorpha, Pallas) larvae in the Modrac Reservoir, Bosnia and Herzegovina. Internationale Revue der gesamten Hydrobiologie und Hydrographie, 80 (3): 443-452.

http://dx.doi.org/10.1002/iroh.19950800309

Firth L.B., Knights A.M. \& Bell S.S., 2011 - Air temperature and winter mortality: Implications for the persistence of the invasive mussel, Perna viridis in the intertidal zone of the south-eastern United States. Journal of Experimental Marine Biology and Ecology, 400 (1/2): 250-256.

http://dx.doi.org/10.1016/j.jembe.2011.02.007

Gibert J. \& Deharveng L., 2002 - Subterranean ecosystems: A truncated functional biodiversity. Bioscience, 52 (6): 473-481.

http://dx.doi.org/10.1641/0006-3568(2002)052 [0473:SEATFB]2.0.CO;2

Hanson W., 1967 - Estimating the density of an animal population. Journal on Research on the Lepidoptera, 6: 203-247.

Hiroki K., 1977 - On the resistance of isolated bivalve gill pieces to oxygen deficiency and hydrogen sulphide. Boletim Fisiologia Animal, 1: 9-20.

Hüppop K., 2012 - Adaptation to Low Food. In: White W.B. \& Culver D.C. (Eds.), Encyclopedia of caves (2 $2^{\text {nd }}$ Ed.). Elsevier: Amsterdam, p. 1-9.

http://dx.doi.org/10.1016/B978-0-12-383832-2.00001-3

Jalžić B., 1998 - The stygobiont bivalve Congeria kusceri Bole, 1962. (Bivalvia, Dreissenidae) in Croatia. Natura Croatica, 7 (4): 341-347. 
Jalžić B., 2001 - The first finding of live stygobiont bivalve Congeria in Lika region, Croatia. Natura Croatica, 10 (3): 213-220.

Jones H.A., 2007 - The influence of hydrology on freshwater mussel (Bivalvia: Hyriidae) distributions in a semi-arid river system, the Barwon-Darling River and intersecting streams. In: Dickman C., Lunney D. \& Burgin S. (Eds.), Animals of Arid Australia: out on their own? Mosman, NSW Australia, p. 132-142.

http://dx.doi.org/10.7882/FS.2007.046

Jourdan J., Bierbach D., Riesch R., Schieß1 A., Wigh A., Arias-Rodriguez L., Rimber Indy J., Klaus S., Zimmer C. \& Plath M., 2014 - Microhabitat use, population densities, and size distributions of sulfur cave-dwelling Poecilia mexicana. PeerJ, 2: e490.

http://dx.doi.org/10.7717/peerj.490

Karatayev A.Y., Burlakova L.E. \& Padilla D.K., 1998 - Physical factors that limit the distribution and abundance of Dreissena polymorpha (Pall.). Journal of Shellfish Research, 17 (4): 1219-1235.

Mackie G.L., Gibbons W.N., Muncaster B.W. \& Gray M., 1989 - The Zebra Mussel, Dreissena polymorpha. A synthesis of European experiences and a preview for North America. Great Lakes Section, Water Resources Branch, Ontario Ministry of the Environment, London, Ontario, Canada.

Matthews M.A. \& McMahon R.F., 1998 - Effects of temperature and temperature acclimation on survival of zebra mussels (Dreissena polymorpha) and Asian clams (Corbicula fluminea) under extreme hypoxia. Journal of Molluscan Studies, 65 (3): 317-325. http://dx.doi.org/10.1093/mollus/65.3.317

McMahon R.F., Ussery T.A. \& Clarke M., 1993 - Use of emersion as a zebra mussel control method: Technical Report EL-93-1. U.S. Army Engineer Waterways Experiment Station: Vicksburg, MS.

Mohr C.E. \& Poulson T.L., 1966 - The life of the cave. MacGraw-Hill, New York, 232 p.

Morton B., 1969 - Studies on the biology of Dreissena polymorpha Pall III. Population dynamics. Proceedings of the Malacological Society of London, 38: 471-482.

Morton B., 1989 - Life-history characteristics and sexual strategy of Mytilopsis sallei (Bivalvia, Dreissenacea), introduced into Hong-Kong. Journal of Zoology, 219: 469-485.

http://dx.doi.org/10.1111/j.1469-7998.1989. tb02594.x

Morton B., Velkovrh F. \& Sket B., 1998 - Biology and anatomy of the 'living fossil' Congeria kusceri (Bivalvia: Dreissenidae) from subterranean rivers and caves in the Dinaric karst of the former Yugoslavia. Journal of Zoology, 245: 147-174.

http://dx.doi.org/10.1111/j.1469-7998.1998. tb00084.x

Morton B. \& Puljas S., 2013 - Life-history strategy, with ctenidial and pallial larval brooding, of the troglodytic 'living fossil' Congeria kusceri (Bivalvia: Dreissenidae) from the subterranean Dinaric alpine karst of Croatia. Biological Journal of the Linnean Society, 108 (2): 294-314.

http://dx.doi.org/10.1111/j.1095-8312.2012. 02020.x

Nalepa T.F., Fanslow D.L. \& Pothoven S.A., 2010 Recent changes in density, biomass, recruitment, size structure, and nutritional state of Dreissena populations in southern Lake Michigan. Journal of Great Lakes Research, 36: 5-19.

http://dx.doi.org/10.1016/j.jglr.2010.03.013
Pathy D.A. \& Mackie G.L., 1993 - Comparative shell morphology of Dreissena polymorpha, Mytilopsis leucophaeata, and the "quagga" mussel (Bivalvia: Dreissenidae) in North America. Canadian Journal of Zoology, 71 (5): 1012-1023.

http://dx.doi.org/10.1139/z93-135

Puljas S., Peharda M., Morton B., Štambuk Giljanović N. \& Juric Z., 2014 - Growth and longevity of the „living fossil" Congeria kusceri (Bivalvia: Dreissenidae) from the subterranean Dinaric karst of Croatia. Malacologia, 57 (2): 353-364. http://dx.doi.org/10.4002/040.057.0208

Ram J.L., Karim A.S., Acharya P., Jagtap P., Purohit S. \& Kashian D.R., 2011 - Reproduction and genetic detection of veligers in changing Dreissena populations in the Great Lakes. Ecosphere, 2 (1): art. 3. http://dx.doi.org/10.1890/ES10-00118.1

Snyder F.L., Hilgendorf M.B. \& Garton D.W., 1997 Zebra mussels in North America: the invasion and its implications [fact sheet]. Ohio: Ohio State University.

Stanczykowska A., 1977 - Ecology of Dreissena polymorpha (Pall.) (Bivalvia) in Lakes. Polskie Archiwum Hydrobiologii, 24: 461-530.

StatSoft Inc., 2014 - STATISTICA (data analysis software system), version 12. http://www.statsoft.com.

Stepien C., Morton B., Dabrowska K., Guarnera R., Radja T. \& Radja B., 2001 - Genetic diversity and evolutionary relationships of the troglodytic "living fossil" Congeria kusceri (Bivalvia: Dreissenidae). Molecular Ecology, 10 (8): 1873-1879.

http://dx.doi.org/10.1046/j.0962-1083.2001.01329.x

Strayer D.L. \& Malcom H.M., 2006 - Long-term demography of a zebra mussel (Dreissena polymorpha) population. Freshwater Biology, 51 (1): 117-130.

http://dx.doi.org/10.1111/j.1365-2427.2005.01482.x

Therriault T.W., Docker M.F., Orlova M.I., Heath D.D. \& MacIsaac H.J., 2004 - Molecular resolution of the family Dreissenidae (Mollusca: Bivalvia) with emphasis on Ponto-Caspian species, including first report of Mytilopsis leucophaeata in the Black Sea basin. Molecular Phylogenetics and Evolution, 30 (3): 479-489. http://dx.doi.org/10.1016/S1055-7903(03)00240-9

Trajano E., 1997 - Population ecology of Trichomycterus itacarambiensis, a cave catfish from eastern Brazil (Siluriformes, Trichomycteridae). Environmental Biology of Fishes, 50 (4): 357-369.

http://dx.doi.org/10.1023/A:1007366119261

Trajano E., 2001 - Ecology of subterranean fishes: an overview. Environmental Biology of Fishes, 62 (1): 133-160.

http://dx.doi.org/10.1023/A:1011841913569

Trontelj P., Douady C.J., Fišer C., Gibert J., Gorički Š., Lefébure T., Sket B. \& Zakšek V., 2009 - A molecular test for cryptic diversity in ground water: how large are the ranges of macro-stygobionts? Freshwater Biology, 54 (4): $727-744$.

http://dx.doi.org/10.1111/j.1365-2427.2007.01877.x

Urian A.G., Hatle J.D. \& Gilg M.R., 2011 - Thermal constraints for range expansion of the invasive green mussel, Perna viridis, in the southeastern United States. Journal of Experimental Zoology Part A: Ecological Genetics and Physiology, 315A (1): 12-21.

http://dx.doi.org/10.1002/jez.644

Ussery T.A. \& McMahon R.F., 1995 - Comparative study of the desiccation resistance of zebra mussels (Dreissena polymorpha) and quagga mussels (Dreissena bugensis). Technical Report EL-95-6, U.S. Army Corps of Engineers, Waterways Experiment Station: Vicksburg, MS. 